\title{
CONCEPT OF EARLY MARRIAGES IN THE LIGHT OF ISLAMIC TEACHINGS -(A RESEARCH STUDY)
}

\section{Syed Muhammad Usman Ghani}

$\mathrm{PhD}$ Scholar

Department: Institute of Islamic Thought and

Civilization(ISTAC)International Islamic

University Malaysia (IIUM)

\author{
Dr Muhammad Sajjad \\ https://orcid.org/0000-0002-0883-5913
}

\author{
Hafza Gull Nasheen \\ PhD Scholar, \\ Bahauddin Zakaria University Multan
}

Article DOI: https://doi.org/10.36713/epra5907

\begin{abstract}
In this article, it has been labored to discuss the issue of child marriage. This has become a burning issue of the date Actually all the member countries of the United Nations are compelled due to the rule of child marriage in which the marriage age has been fixed. Actually, it is a contradictory law due to the contradictory theology about the marriage perspectives of the Islam and the West. Infact Islam focuses the importance of Faith, male \& female honour innosece and prefer the hereafter success on the worldly lusts and earnings while the philosophy of the West about this world and hereafter is totally opposite. The West prefer the worldly lusts, enjoyment and success on the Hereafter success and eternal life. All the contradictory issues among the West and Islam should be perceived in this perspectives. So, in this article it has been endeavoured to elaborate this contradiction which has divided the Muslims into different sects.
\end{abstract}

KEY WORDS: Child marriage, Islam, Librals, West, Quran, Sunnah

\section{INTRODUCTION}

There are generally two opinions in our circles about the marriage of early ages, but there is no difference in Islamic circles about marrying after puberty. Those who seek to limit the age of marriage are, in fact, trying in vain to please other forces, not Islam. Let us first study the insistence and intentions of global public opinion and the ruling powers on child marriages, then explore the ideological differences in the Islamic world, and finally make a moderate comment and summary.

One of the major problems in our society is the age of marriage. On the one hand, it is customary in some tribes and families to marriage their siblings in early ages, and on the other hand, there are cases of delay in marriage. Apparently, these are two simple issues, but the numerous problems and crimes that occur in the society are related to these two issues, so it is necessary to discuss them separately. It is necessary to find a solution to these problems by seriously considering them, otherwise it is impossible to solve the problems that arise as a result.

\section{The Viewpoint of the first class, the liberals}

The function of parliament is to legislate to protect and promote the rights of the people. But sometimes very interesting legislation is enacted. One such law was recently passed by the Standing Committee on Human Rights of the Senate of Pakistan in the form of a bill banning marriage under the age of 18 . The bill was earlier enacted by the Sindh Assembly. By the way, the Sindh Assembly is second to none in making and passing such bills and laws. Earlier, an interesting bill was introduced on conversion, according to which anyone who wants to convert to Islam under the age of 18 will not be allowed to do so. According to the constitution of Pakistan, the Qur'an and There can be no legislation that contradicts the teachings, rules and instructions stated in the Sunnah. But in both of these laws, I think the meaning of the teachings of the Qur'an and Sunnah has been ignored. Nowhere in the Qur'an and Sunnah is there an age for marriage, but it is obvious that leave is given at puberty. As far as marriage (engagement) is concerned, parents can 
also decide on the engagement of the children. However, according to the hadiths, the leave under the option of puberty will depend on the children being young (adults) and consenting.

The first problem is to get girls married to an early age, this is a problem that is facing most of the countries of the world including Pakistan and that is why many countries have legislated on it. Not until the causes that cause this problem are eliminated.

According to UNICEF, the highest rates of child marriage are in the Arab world, and in Saudi Arabia alone, girls under the age of five thousands girls who are under16, are married off annually to men over the age of 30, although Saudi law fixed the minimum age for marriage is 16 years old. Even in Arab countries, the rate is higher in rural areas than in cities. In cities, attention is paid to the education and employment of girls.

The rate varies from country to country, with the youngest Age marriages taking place in Yemen, which has risen dramatically in the past two years, from 32 percent to 66 percent, a ten-year low. Najud Ali, the oldest divorced man, is also from Yemen. In Sudan the rate is $52 \%$, in India $47 \%$, in Mauritania $35 \%$, in Palestine $21 \%$, in Egypt $17 \%$, in Lebanon 6\%, while in Tunisia and Algeria the rate is relatively low and there are $2 \%$ underage marriages.

According to UNICEF, 15 million women in developing countries are married off before they reach the age of 18 , of which $50 \%$ are under the age of 15. The 1989 Child Rights Act According to the law, a person under the age of 18 will be considered a child, so according to international law, marrying before that will be considered a crime. Because it has many negative effects on daughters, their education remains incomplete and Their frail shoulders carry responsibilities that they cannot bear, including household chores. Becoming a mother at an early age also has a negative impact on their own health and that of such mothers and their newborns during motherhood and Deaths occur, as well as domestic and physical violence, as well as mental illness.

Although legislation has been passed in most countries and some countries have set a minimum age of 18 , some 17 and some 16 years, the issue is still not under control, according to the Arab Spring. Later its rate has increased and a new type of marriage has been introduced which is called Nikah Sütråh(ستره) . "Sütråh" means shield, refuge and protection, and applies to marriages in the name of providing protection and shelter to refugee women and girls in war-torn areas such as Syria, Yemen and Libya. And the insecurity has made these refugees wonder and wonder that the priests of lust are taking advantage of their plight and arranging marriages with their mothers, sisters and daughters. Instead of being ashamed and ashamed of what he has done, he is calling this process as shelter and relief for the refugees. The father, who is suffering from hunger and hardship and is suffering from sexual predators, has treated his daughter's reputation in various ways. Instead of sacrificing the lust of beasts, he considers it safe to hand over the marriage to a priest of the same lust in the name of marriage. According to the statistics so far, in Saudi Arabia, Lebanon, Turkey and Jordan a majority of matric and FA teenagers have found.

The reasons for early marriage are also different in different societies, sometimes due to religion, girls are given in marriage to the minor Age, sometimes for economic reasons, in Yemen, the reason is tribal and family traditions, Yemeni society In Sudan, it is considered desirable to marry at the age of ten or twelve, due to poverty, poverty and ignorance of the law, while in Egypt, parents marry teenage girls as soon as possible to relieve them of their responsibilities. Three times since 2003 , the Iraqi parliament has proposed a minimum age of nine years for a girl's marriage, according to an Arab magazine, which was demanded by followers of Jaffaria jurisprudence. According to him, a girl becomes obligated at the age of 9 and this includes the responsibilities of marriage. In many societies, it is believed that early marriage protects girls from illicit relations and sexual abuse. The dignity of the girl and the family is protected.

Legislation to prevent underage marriage in Pakistan is also being debated, and the Islamic Ideological Council may soon raise the issue again, but it must be remembered that the only solution to any problem is to Legislation does not happen, but sometimes legislation creates more problems, a clear example of which is the above-mentioned Jordanian law. Therefore, in Pakistan, instead of emphasizing legislation on child marriage, work on education and public awareness Need.

\section{The point of view of the second class, the majority of scholars}

The majority of scholars consider it permissible to marry a young girl before puberty. Many scholars have also quoted this consensus, and only Ibn Shabrama and Uthman al-Bati, may God have mercy on them, oppose this consensus The evidence for the Almighty's interpretation. is:

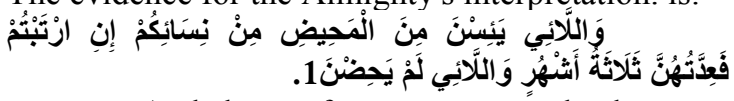

And those of your women who have no hope of menstruation, if you doubt (as to what will be their prescribed period), then their prescribed period is three months. And for those women who

\section{Al-Tlaq, 65:4}


have not yet menstruated (their prescribed period is also the same). As for the pregnant women, their term is till the birth of the child. And whoever fears Allah, He makes his matter easy for him.

This verse proves that Allaah mentions the 'iddah of a girl who gets divorced before her period, and this means that she is not an adult, and there is no divorce or annulment of marriage until then. Unless the marriage contract is valid.

The majority of scholars are of the opinion that if the wife becomes an adult, she will not be given any choice [to live with her husband or not]. The Prophet (peace and blessings of Allaah be upon him) said to 'Aa'ishah when she was 6 or 7 years old. She got married but the Prophet (peace and blessings of Allaah be upon him) did not give her any authority when she became an adult.

Here are some things to keep in mind:

1. Only the father has the right to marry a little girl as a child, no one else has this right, this is the position of the majority of scholars, and this is correct, so the position of those who give this option to the grandfather is not correct, the same Similarly, their position is not correct which allows other saints besides the father to get married in childhood but they are also convinced of the authority of the girl when she becomes an adult. him) said:

Imam Shafi'i (may Allaah have mercy on

No one but the father can marry a girl at the age of fifty-five, whether the girl is a virgin or a girl who becomes a widow in infancy, whether or not her permission is included in it, as well as both [virgins or It is also wrong to marry one of the widows and then give the option in case of adulthood, so if a girl is married to someone other than the father, the marriage will be annulled, due to such a marriage. Spouses will not inherit from each other, nor will divorce take place, but the ruling on this marriage will be invalid in all matters, so divorce and inheritance will not apply to it. 1

And if the orphan girl is 9 years old, then it is permissible to marry her with her permission, but when she becomes an adult, she will not be allowed to do so, and it is not permissible to marry her before the age of 9, according to Imam Ahmad. According to this, it is famous and it has been declared valid by Shaykh-ul-Islam Ibn Taymiyyah (may Allah have mercy on him).

\footnotetext{
1 Al-Shafie, Muhammad bin Idrees, Kitabul Umm, Darul Kutub Al-Ilmiyah, Beirut, $1400 \mathrm{AH}$ p, $18 / 5$
}

2. This marriage should be performed keeping in view the interest of the child and not the interest of the father of the child or anyone else. on him) said:

Imam Shoukani (may Allaah have mercy

In the case of marriage without a credible interest, the marriage will not take place from scratch, so it is not only permissible for the ruler, but it is also obligatory for him to separate the young girl and her husband, unless his consent is proved after reaching adulthood. A minor girl has the right to flee whenever she wants, whether she is an adult or not. 2

Marriage with a young girl does not mean that she should be given leave with her husband, so the leave will be only when she is able to have intercourse.

4. Sexual intercourse has nothing to do with puberty. Whenever a girl is able to have sexual intercourse, her husband can marry her.

Therefore, if a minor girl marries someone other than the girl's father, such as an uncle, grandfather, or brother, then the marriage will not be valid, and if the marriage is for the benefit of someone other than the father or the girl herself. Even if she is gone, the marriage will not be valid. Similarly, the girl will not be divorced from her husband before she is able to have intercourse. Also, it is not a condition for her to be an adult, but it is enough for her to be able to have intercourse.

Every Muslim should bear in mind that all the commandments of the divine law are full of wisdom, the Shari'ah is for the betterment of individuals and society, just as a father hastens to the marriage of his daughter. The girl has no one else to benefit from it.

Sheikh Abdullah bin Abdul Aziz Al Jabreen says:

"It is clear that it is difficult for us to have a close relationship, and it is possible that sometimes marrying a little girl may take time, for example, in a place or time when there is a lot of temptation, or the girl's father at all. If she is poor, unable to earn, or unable to support her family for any reason, then the little girl needs a protector who will protect her as well as protect her. He should also bear the expenses, so in such a situation the little girl should be handed over to a person who takes full care of her and he can be the father, so the father should marry his little girl to such a person. With which the bright future of the girl is connected, so the father should not waste the opportunity to have a proper relationship because a

2 Muhammad Ali Al-Shaukani, Wablul Ghammam Ala Shifa ul Auwam, Maktabah Ibne Taimiyah Cairo, P, 33/2 
good relationship is not always found, and usually getting married in childhood, including the girl's present and future in religion and the world. Proves useful ".1

After mentioning these interests, Sheikh Mohtarma also said:

Therefore, the father should fear Allah Almighty, and fulfill the responsibility imposed by Allah Almighty in a good manner, keeping the interests of the girl child in mind while marrying him, so that he may get more benefits from it.

After the benefits, the scholars have also mentioned some of the conditions for ensuring the rights of the girl child by the father in marriage, some of which are as follows:

1. There should be no enmity between the daughter and the father.

2. There should be no animosity between the girl and the future husband.

3. The father should not marry the girl to a person whose cause of harm to the girl is obvious, for example: very old or self-defeating person, etc.

4. Give in marriage to a suitable person who does not hesitate to pay the dowry. 2

\section{Small girl's wedding:}

The general scholars are of the opinion that the Shari'ah does not specify the age of the child for marriage, so that the child should not be married before that age.

The proof of this is in the Book of Allaah and the Sunnah of the Prophet (peace and blessings of Allaah be upon him) and the consensus of the scholars. meaning):

1 - Allaah says (interpretation of the

And those of your women who have despaired of menstruation, if you are in doubt, their 'iddah is three months, and also those who have not yet begun to menstruate. 3

This verse clearly indicates the issue we are discussing, and it describes the 'iddah of a divorced woman who has just given birth and has not yet begun to menstruate. on him) said:

Imam Baghawi (may Allaah have mercy menstruated.
1Wilayatul Tazweej Al-Sagheerah, Publisher: Mujalah Al-Bahooth Al-Islamiyah, P 256/33 2Mujalah Al-Bahooth Al-Islamiyah, P 257/33 3 Al-Tlaq, 65:4
That is, those young people who have not yet menstruated, then their 'iddah is also three months. 4

And Ibn Qayyim (may Allaah have mercy on him) said:

The 'iddah of a woman who is not menstruating is of two types:

One is a young woman who has not yet menstruated, and the other is an older woman who has lost hope of menstruation.

Allaah, may He be glorified and exalted, explained the 'iddah of these two types of women:

And those of your women who have despaired of menstruation, if you are in doubt, their 'iddah is three months, and also those who have not yet begun to menstruate. 5

That is, their 'iddah is the same. "6

\section{Arguments of Sunnah:}

Aisha (may Allaah be pleased with her) said:

The Prophet (peace and blessings of Allaah be upon him) married her when she was only six years old, and when she left, she was nine years old, and she stayed with the Prophet (peace and blessings of Allaah be upon him) for nine years. 7

According to the correct view of the scholars, the father of this young girl will marry her.

Shaykh al-Islam Ibn Taymiyyah (may Allaah have mercy on him) said:

No one can marry a woman without her permission, as the Prophet (peace and blessings of Allaah be upon him) commanded, and if he dislikes her, he cannot force her to marry him, but he can marry a young virgin. Her father will marry her, and she has no right to permission. "8

\section{Consensus} on him) said:

Ibn 'Abd al-Barr (may Allaah have mercy

4 Imam Baghvi, Abdullah bin Ahmad bin Ali AlZaid, Tafseer ul Baghvi, Darul Kutub AlIlmiyah, Beirut, p, 52/8

5Al-Tlaq, 65:4

6 Muhammad bin Abi Bakar bin Ayub ibne Qayyam Al-Jauziyah, Zadul Maad fi Hadye Khairul Abbad, Muassisah Al-Risalah, 1998, p, 595/5

7 Imam Abu Abdullah, Muhammad bin Ismail AlBukhari, Sahih Bukhari, Darul Kutub AlIlmiyah, Beirut, 1412AH, Hadith no, 4840

8 Imam Ibne Taimiyah, Ahmad bin Abdul Haleem, Haleem, Majmu ul Ftawa, Wizaratul Shoun Al-Islamiyah Wal-Dawah Wal-Irshad, Saudia Arabia, 2004, P, 39/32 
There is a consensus among the scholars that a father can marry his young daughter and he does not need to consult her, because the Prophet (peace and blessings of Allaah be upon him) married 'Aa'ishah bint Abu Bakr (may Allaah be pleased with her). He was only six or seven years old when his father married the Prophet (peace and blessings of Allaah be upon him).1 him) said:

And Ibn Hajar (may Allaah have mercy on

The father of the little girl will marry her.2 her. 2

Leaving the little girl and entering her:

It is not obligatory to enter into a marriage contract, because it is well known that sometimes an older woman gets married, but it does not require her to enter into it, and it can be explained in this way. That:

Sometimes a divorce takes place after the marriage contract has taken place, and before the intercourse takes place, that is, before the leave, then there are some rulings on that; If so, he will have to pay half the mahr, and he will not have any 'iddah. meaning):

Allaah says (interpretation of the

And if you divorce them before you have touched them, and you have given them a dowry, then give them half of the dowry they have been given. The knot of marriage is that he forgives. 3 meaning):

And Allaah says (interpretation of the

O you who believe, when you marry believing women and then divorce them before you have touched them, you have no right to 'iddah on them which you count, so give them some of them and send them away in a good manner. 4

Therefore, if a young girl gets married, she will not be handed over to her husband until she is able to leave and be intimate with him, and that does not require her to be an adult. Rather, one should have the strength to tolerate intimacy, and if there is a divorce after taking leave, then his' iddah will be three months, as mentioned above.

In this regard, the scholars are of the opinion that those who think that they can have

1 Yusuf bin Abdullah Al-Nimri AlUndulsi, Al-Istizkar Al-Jamae Li-Mzahib Fuqha Al-Amsar wa Ulema Al-Aqtar, Darul Kutub AlIlmiyah, Beirut, 2010, p, 49-50/16

2 Ahmad bin Ali bin Hajar Al-Asqlani, Fathul Barii, Darul Marifah, Beiurut. 1379AH, p, 239/9

3 Al-Baqarah, 2: 237

4 Al-Ahzab, 33: 49 intercourse with a little girl or have intercourse with her are rejected.

Imam al-Nawawi (may Allaah have mercy on him) said:

The time for a young girl to leave and enter is:

If the husband and the guardian agree on something that does not harm the little girl, it will be done, and if they disagree, Imam Ahmad and Abu Ubaid say:

A nine-year-old girl will be forced to do so, but not a younger girl.

And al-Shaafa'i and al-Malik and Abu Haneefah (may Allaah have mercy on them) said:

It is permissible to tolerate sexual intercourse, and it differs from woman to woman, and it is not permissible to impose an age limit on it, and this is also valid, and there is no limit to the age in the hadeeth of 'Aa'ishah (may Allaah be pleased with her). Nor does it say that if she can afford it before that age, she will not be allowed to leave.

Nor is it permissible for a person who is unable to have sexual intercourse even when he is nine years old.

Dawoodi (may Allaah have mercy on him) said:

Ayesha (may Allah be pleased with her) was a very young woman. 5

\section{The viewpoint of the third class}

Marriage of Hazrat Ayesha:

Our jurists are mistaken in this matter because of a narration. This narration has been narrated with the most authentic chain of transmission in all the authentic books of hadith, and this is the narration on the basis of which our jurists have issued a fatwa justifying minor Age marriages. Have to give This narration is attributed to Ayesha in which she says:

The Prophet (peace and blessings of Allaah be upon him) married me when I was six years old. After that we came to Madinah ... Then (during the leave) I was not disturbed by anything except that the Messenger of Allaah (peace and blessings of Allaah be upon him) came and (the Ansari women) visited me. In those days it was a year. In another narration it is said that Urwah Ibn Zubayr said that Hazrat Khadijah passed away three years before the migration of Hazrat Akram to Madinah. He did not get married for almost two years. Then he married Ayesha when she was six years old. And Ayesha left when she was nine

5 Allama Ghulam Rasool Saeedi, Sharah Sahih Muslim , Maktabah Mujadidyah Karachi, p, 206/6 
years old. In another narration he said the same thing in other words. And in a fourth narration it is said that (Hazrat Ayesha said) the Holy Prophet (PBUH) married me when I was seven years old.1

This is a narration which proves that

Hazrat Akram had married Hazrat Ayesha Siddique at the age of six years and when she left, she was nine years old at that time. This hadith has proved to be very difficult for the scholars. As far as getting married at the age of a few is concerned, on the basis of this he issued a fatwa that marriages of minor Ages may be permissible. Because if minor Age marriages were not permissible, he would not have married Hazrat Ayesha at the age of six. But as far as taking leave at the age of nine is concerned, which is not generally considered the age of puberty, this hadith is still considered difficult. In general, our jurists and scholars of the ummah have tried to escape by putting forward some unusual and exceptional examples of Africa, etc., proving that girls in some special cases, especially in hot countries, become adults even at the age of nine. Happens. But the answer is obvious. Because it is not a matter of Africa and it is not a question of special cases. Makkah is still on the earth's map. It is still as hot a country as it used to be in the time of the Holy Prophet. Girls are still born there and usually do not reach adulthood by the age of nine. The family of Siddiq Akbar was the source of nobility and sanctity. That is not a needless statement. There we can't even imagine these special circumstances and specific data. Elsewhere, girls reach the age of nine. Therefore, this hadith is still difficult.

This hadith has also been narrated in Sahih Bukhari, Sahih Muslim, Sunan Abu Dawood, Sunan Nisa'i and all other authentic books of hadith. There is no doubt that this hadith cannot be objected to. On the basis of this same hadith, Jim Ghafir of jurists and scholars has been convinced of the legitimacy of minor Age marriages and those who are convinced of the legality of minor Age marriages are also convinced of the legitimacy of either minor girls. They are being forced to attribute this incident to the characteristics of the Holy Prophet.

But on this occasion, the question may arise as to why the above-mentioned hadith, no

Qur'an. Even it a hadeeth is a strong hadeeth, its denial does not imply that it is saheeh. The scholars of principle have made it clear that even if the news is authentic but it is against the clear text of the

1 Sahih Bukhari, Hadith no, 4849
Qur'an, it cannot be accepted. In the previous pages, we have seen that the clear text of the Holy Qur'an tells the age of marriage to puberty. Therefore, in the case of minor Age marriages, the Holy Qur'an, in response to this, when the scholars have taken the position that "if the hadith is saheeh, then it is obligatory to accept it. And if any clear text of the Holy Qur'an If it goes against the text of the Holy Qur'an, then it is necessary to leave it, because no one could understand the texts of the Holy Qur'an better than the Holy Prophet. When any word or deed of the Holy Prophet is against the text of the Holy Qur'an, it means This Qur'anic text does not mean what we understand, but it means something else. " So the intellect is amazed. I am very sorry that no sensible person can accept this position. Even the narrators themselves did not take this position.

The meaning of the clear text is that the verse of the Holy Qur'an has its own meaning and purpose. It is so clear that it cannot have any other meaning. If a news item contradicts the clear text of the Holy Qur'an, then why does it not mean that that news item alone should be misinterpreted? What is the competition between suspicion and certainty? The Holy Qur'an is definite and the news is the only suspicion. So why not consider Khabar Wahid as wrong?

\section{Criticism of Ayesha's Hadith}

He later said that when we review this narration of Hazrat Ayesha, this narration is not acceptable in any way. The result of this narration is that the marriage of Hazrat Akram to Hazrat Ayesha Siddique took place in Ba'ath. Because according to the popular saying, after the revelation, he stayed in Makkah for thirteen years and Hazrat Khadijah died three years before the migration, that is, in prophethood and he did not get married for two years. Therefore, one year before the migration in Prophethood, when Ayesha got married, Ayesha was six years old at that time, that is, Ayesha was born in Prophethood. But this is wrong.

1) First of all, let us see that this is refuted by a narration of Bukhari himself in which Hazrat Ayesha herself says that when this Ayah revealed

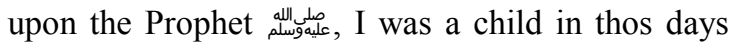
and plays with my age fellows.

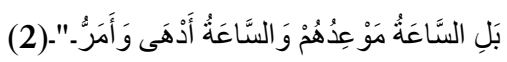

Surah Al-Qamar was revealed in about 5 prophecies. If Ayesha was a child and used to play in 5 prophecies, then how can she be born in 5 
prophecies? This narration proves that Ayesha must have been at least five or six years old in the 5th Prophethood. Because at a young age, it is unthinkable for me to play and understand that these are the verses of the Holy Qur'an and later this incident will be remembered by them. It should be noted that this narration is also of Sahih Bukhari and according to the chain of transmission it is of the same level. The degree of Bukhari etc. is the tradition that is presented in connection with their marriage.

Hazrat Ayesha and Hazrat Fatima:

2) Hazrat Ayesha was five years younger than Hazrat Fatima, so Asad al-Ghaba per Ma'rifat al-Sahaba says:

Hazrat Fatima was about five years older than Hazrat Ayesha. 1

Therefore, in order to find out the year of birth of Hazrat Ayesha, we have to look at the year in which Hazrat Fatima was born. Asad al-Ghaba fi Ma'rifatah al-Sahaba says that Hazrat Fatima was born in the year when the Ka'bah was being built and the Holy Prophet was 35 years old. 2

There is another place in the same book that:

Hazrat Abbas went to Hazrat Ali and Hazrat Fatima was telling Hazrat Ali that I am older than you. Hazrat Abbas replied that Fatima was born at a time when the Quraysh were building the Ka'bah and Ali Were born a few years ago. 3

In tabqaat Ibn Sa'd are as follows:

Hazrat Fatima is the daughter of Rasoolullah. His mother is Hazrat Khadija bint Khulmad bin Asad Ibn Abdul Aziz Ibn Qusay. Hazrat Fatima was born from the womb of Hazrat Khadija in the days when the Quraysh were building the Baitullah and this incident took place five years before the Prophethood.4

There is another place in the same book that:

Hazrat Abbas once went to Hazrat Ali's house and Hazrat Fatima was saying to Hazrat Ali that I am older than you. Hazrat Abbas said: Look, Fatima! You were born in the days when the Quraysh were building the Ka'bah and the Holy Prophet was thirty-five years old and look Ali! You were born a few years before that. 5

Hazrat Fatima and Hazrat Ali

1 Ibnul Atheer, Abul Hassan, Ali bin Abi AlKaram, Asadul Ghabah fi Marifahtul Shabah, Darul Fikr, Beiurut, p, 377/ 4

2 Asadul Ghabah fi Marifahtul Shabah, p, 377/ 4

3 Asadul Ghabah fi Marifahtul Shabah, p, 28/ 2

4 Asadul Ghabah fi Marifahtul Shabah, p, 11/8

5 Asadul Ghabah fi Marifahtul Shabah, p, 18/ 8
In all these statements, according to Hazrat Abbas, Hazrat Fatima was born 5 years before the Prophethood while the Quraysh were building the Kaaba and Hazrat Mubarak was 35 years old. But the fact cannot be ignored that in these statements Hazrat Fatima herself claims that she was older than Hazrat Ali.

The companions of Sero history agree that the burden of raising Hazrat Ali was borne by Hazrat Akram and Hazrat Ali was brought up in the footsteps of Hazrat Ali (because Abu Talib's financial condition was not much better. Abdul Muttalib's death). Since it was Abu Talib who brought up the Holy Prophet (saw), he may have accepted the responsibility of raising Hazrat Ali (as) in order to repay this favor. The age of Hazrat Ali (as) was ten years at the time of his resurrection. He was born 10 years before the Prophethood. It is noteworthy that in the house where Hazrat Fatima was growing up, in the same family, Hazrat Ali was also being brought up. It is very unlikely that Hazrat Fatima (may Allah be pleased with her) was mistaken for the fact that she is older than Hazrat Ali (may Allah be pleased with her). The child is five years younger, he considers himself to be a child who is five years older than him. Neither should be less than five years old. Rather, this small increase should be very modest, ie a few months. So that some of Hazrat Fatima's mistake can be justified.

This is also supported by the narration of Kalbi which has been narrated by Sahib Istiyat regarding the age of Hazrat Fatima. Sahib Istiyat writes that:

He said: O Abu Muhammad! What was the total age of Fatima bint Rasoolullah?

How old was Hazrat Fatima at the time of her death? There is a difference. Zubair Ibn Bakr has narrated from Abdullah Ibn Al-Hasan that he used to visit the court of Hisham Ibn Abdul Malik and Kalbi was also present there. Hisham Abdullah Abdullah Ibn Al-Hasan said that thirty years. Hisham then asked Kalbi what was the total age of Hazrat Fatima? Kalbi said that for thirty-five years, Hisham said to Abdullah Ibn al-Hasan: $\mathrm{O}$ Abu Muhammad! Listen to what Kalbi is saying and Hisham gave more importance to Kalbi's statement. Abdullah Ibn Al-Hasan replied: O Commander of the Faithful! Ask me about my mother and ask Kalby about her mother. 6

According to a popular saying, Hazrat Fatima passed away in $11 \mathrm{AH}$, six months after the death of Hazrat Akram. If, according to Kalbi,

6Abu Amar, Yosuf bin Abdullah bin Muhammad bin Abdul Barr, Al-Estiaab Fi Maarifatul AlAshab, p, 482/2 
Fatima's death is acknowledged at the age of thirtyfive, she must have been born 12 years before Prophethood. While the birth of Hazrat Ali has been acknowledged in the prophecy 10 years ago. This narration of Kalbi confirms the statement of Hazrat Fatima.

It should be noted that there is no weight in the saying of Hazrat Abdullah bin Al-Hassan: "O Amir al-mu'minin! Ask me about my mother and ask Kalbi about her mother." Because the statement of Hazrat Fatima herself and her claim is also supporting the statement of Kalbi. Therefore, there is no reason for us to ask Abdullah Ibn Al-Hassan about the age of Hazrat Fatima and not to ask Hazrat Fatima herself. No matter how weak the Kalbi traditions are according to the narrators in terms of rules, but in history it is not weak. Clubby is the most important part of our history. In this issue with the characteristic, it cannot be ignored that even in the opinion of Caliph Hisham Ibn Abdul Malik, the opinion of Kalbi himself was preferable to that of Abdullah Ibn Al-Hasan. As for the statement of Hazrat Abbas, we do not need to confuse his statement.

The reason for the difference in dates:

In order to apply these two statements, we must keep in mind one thing in principle, and that is that the Arabs did not have a calendar before Islam. So they were usually accustomed to remembering different events more than other important and famous events. For example, the Holy Prophet was born this year while Mecca was attacked by the Companions of the Elephant. Hazrat Fatima was born in the year when the Quraysh were building the Kaaba. It is not uncommon for events to be remembered in this way for a gap of one or two years, and sometimes several years. In addition, if both the year of birth and the year of death are included in the statement of ages, then two years are added and if these two years are not counted, then two years are reduced. Because it is clear that not everyone who is born is born in the month of Muharram and not everyone who dies dies in the month of Dhi Al-Hijjah so that the year of birth and the year of death can be considered necessary. Therefore, it is quite possible that Kalbi added the year of birth and the year of death and said that Fatima was thirty-five years old at the time of her death. Similarly, counting the twenty-three years of Prophethood and ten years before it, the year of Fatima's birth becomes 10 years before Prophethood. In the same way, the companions who have mentioned the age of Hazrat Ali at the time of Prophethood as ten years. He may have omitted the year of birth and stated his age. Otherwise, in fact, Hazrat Ali was born 11 years before Prophethood.

We believe that Hazrat Ali was born 11 years before Prophethood and Hazrat Fatima was born 10 years ago. And the difference between the two may be increasing by a year or a few months. For this reason, Hazrat Fatima may have been mistaken that she is older than Hazrat Ali, but this was not the case. Hazrat Abbas had told Hazrat Fatima to remove this mistake that Hazrat Ali was older than her. That is, there was a gap of a year or a few months between the two.

If the birth of Hazrat Fatima is acknowledged in $10 \mathrm{BC}$, then the birth of Hazrat Ayesha should be in $5 \mathrm{BC}$. And at the time of marriage, that is, in the 12 prophecies, their age should be seventeen years, and if the year of birth or the year of marriage is omitted, then their age becomes sixteen years.

Hazrat Ayesha and Hazrat Asma:

3) This is also supported by another statement which Imam Ibn Katheer has mentioned in his famous book "Al-Badaita wa Al-Nahaita".

And in terms of death, Hazrat Asma is the last of all the Muhajireen and his emigrants is his sister Ayesha. His father is Abu Bakr Siddiq. His grandfather is Abu Atiq. His son is Abdullah. And his The husband is Hazrat Zubair and all of them are companions. Hazrat Asma was involved in the battle of Yarmouk with her son and husband. She was ten years older than her sister Ayesha. This year (in $73 \mathrm{AH}$ ) I had to witness the murder of my son Abdullah five days after this incident and there is a saying that ten days later there is a third saying that it is twenty days later and there is a fourth saying that something above is twenty days later and there is a fifth saying that a hundred days later and This is a well-known saying. At the time of his death, Hazrat Asma was a hundred years old.1

This is also supported by the statement of Sahib Mushkoot Al-Masabih Imam Wali-ud-Din Abu Abdullah Muhammad Ibn Abdullah AlKhatib. He has recorded it in his book Akmal Fi Asma Al-Rijal. He writes:

"Asma bint Abi Bakr, this is Asma bint Abi Bakr Siddiq. They are called Zaat al-Nataqeen. The other piece is that she wrapped the other piece around her waist as a narrator. She is the mother of Abdullah Ibn Al-Zubayr. She became a Muslim in Makkah very early. Only seventeen men had converted to Islam before her. She was ten years older than her sister Ayesha. She died ten or twenty days after the martyrdom of her son. But he was hanged. He was 100 years old at the time of his death. 2

1 Imadul Deen Ismail bin Umar bin Kathir, AlBidayah Wal-Nihayah, Darul Fikr Beiurut, P, $346 / 8$

2 Al-Khateeb Tebrizi, Muhammad bin Abdullah Mishkatul Msabih, Maktbah Ahle Hadith Lahore, Zamimah, 587 
Asad al-Ghaba says:

Hazrat Asma was older than Hazrat Ayesha. Hazrat Ayesha was his sister on behalf of her father. Abdullah Ibn Abi Bakr was his real brother. Abu Naeem says that he was born 27 years before the date (ie migration) and when he was born, his father was a little over twenty years old. Hazrat Asma had converted to Islam after seventeen men. 1

It is clear from these descriptions that Hazrat Asma was born 14 years before Prophethood. Because he died in 73 AH, he was one hundred years old. Therefore, they should have been born 27 years before the Hijrah and 14 years before the Prophethood. She was ten years older than Ayesha. Therefore, Ayesha should have been born 4 years before Prophethood and 14 years of Prophethood when she got married. She should have been 16 years old.

All these evidences prove that Ayesha was not less than sixteen or seventeen years of age at the time of marriage. The tradition mentioned above regarding the marriage of Hazrat Ayesha. In it, of course, the word ten has either been omitted from a narrator by mistake or has been omitted intentionally. And so it has become six of sixteen and nine of nineteen.

4) Regardless of the above-mentioned narration, all the traveling companions agree that Hazrat Ayesha was married to the Holy Prophet in 10 Prophets. And the correct view about the leave is that it took place in Shawwal $2 \mathrm{AH}$, that is, 15 Prophets Because the stay of the Holy Prophet in Makkah has been for at least thirteen years. This is a well-known saying and it has been preferred by all the companions and narrators. Otherwise, the second view is also of fifteen years. Therefore, it is stated in Ibn Sa'd:

A man came to Ibn Abbas and said that revelation was revealed to the Messenger of Allah for ten years in Makkah and ten years in Madinah. Ibn 'Abbas said, "Who says that?" Revelation was revealed to you in Makkah for fifteen years or more. 2

Hazrat Ayesha's leave:

But another narration has been narrated from Ibn Abbas himself that he stayed in Makkah for thirteen years. He then migrated, so it is generally accepted that he lived in Mecca for thirteen years. Therefore, more than three years had passed since the 10th Prophethood. Then we should see when Hazrat Ayesha left after the migration. Two views are quoted in this regard. The first opinion is of Shawwal $1 \mathrm{AH}$ and the second

1 Asadul Ghabah fi Marifahtul Shabah, p, 292/ 5

2 Tabqaaat Ibne Saad, p, 333-334/1 opinion is of Shawwal $2 \mathrm{AH}$. But the correct view is of Shawwal $2 \mathrm{AH}$. Because the migration took place in Rabi-ul-Awal $1 \mathrm{AH}$. The family of the Holy Prophet and the family of Hazrat Siddiq Akbar were not present during the migration. After reaching Madinah and getting all kinds of satisfaction, they were called after arranging a house etc. 3

Upon reaching Madinah, Hazrat Ayesha fell ill and lost all her hair. Your marriage then took place when the hair grew back and up to the shoulders. (See Ayesha's own narration of Bukhari, p. 204, vol. 2) Obviously, all these things could not have happened in just six or seven months. That is why Alamiyah Aini had to say in Sharh Sahih Bukhari regarding the departure of Hazrat Ayesha:

"It is very strange that he left seven months after the migration. This statement is very weak. He left in Shawwal $2 \mathrm{AH}$ after returning from the battle of Badr."4

This has also been supported by Sahib Isti'ab. So he says:

The Prophet (peace and blessings of Allaah be upon him) married 'Aa'ishah three years before the migration in Shawwal 10, and brought her to Madinah in Shawwaal (2 AH) eighteen months after the migration.5

Marriage of Hazrat Fatima:

Asad al-Ghaba says:

Hazrat Fatima was married four months after the marriage of Hazrat Ayesha. 6

Therefore, we should also look at when Hazrat Fatima was married. In this regard, AlAsaba says:

Hazrat Ali had married Hazrat Fatima in Muharram $2 \mathrm{AH}$, ie four months after the marriage of Hazrat Ayesha.7

But this statement is wrong

because in Sahih Bukhari the statement of Hazrat

Ali himself is against it. Sahih Bukhari says:

Hazrat Ali (AS) said: I had a she-camel which I got as booty in the battle of Badr and another she-camel was given to me by the Messenger of Allah (SAW) out of the portion which Allah Almighty gave you as a fee. I intended to bring Hazrat Fatima bint Rasoolullah on leave and I talked to a goldsmith of Banu Qainqa 'to go

3 Tabqaaat Ibne Saad, p, 43/8

4 Allama Badrul Deen Mehmood bin Muhammad Al-Aini, Umdatul Qari, Maktabah Jebrail, p, 96/8

5Abu Amar, Yosuf bin Abdullah bin Muhammad bin Abdul Barr, Al-Estiaab Fi Maarifatul AlAshab, p, 744/2

6 Al-Estiaab Fi Maarifatul Al-Ashab, p, 377/4

7 Al-Estiaab Fi Maarifatul Al-Ashab, p, 365/4 
with me and we brought Azhar grass from the forest. I intended to bring Azhar grass. I will marry her with the money I will get by selling her to the hands of goldsmiths. (Then it is narrated how Hazrat Hamza tore the hips of these camels as this story does not belong to our subject.) Must not be considered for duplication). 1

This shows that Ali was not married until after the Battle of Badr. The battle of Badr took place in Ramadan $2 \mathrm{AH}$. Therefore, your marriage can take place as soon as possible in Muharram 3 AH.

Sahib Isti'ab and Sahib Asad al-Ghaba have clarified this further. Asad al-Ghaba says:

He married Hazrat Fatima to Hazrat Ali after the battle of Uhud. The second statement is that Hazrat Ali married Hazrat Fatima to Hazrat Ayesha four and a half months after her departure, Was married seven and a half months after the marriage. "2

Sahib Isti'ab writes:

And the Prophet (peace and blessings of Allaah be upon him) married Fatima to Hazrat Ali (as) after the battle of Uhud. There was a gap of nine and a half months in between. 3

The battle of Uhud took place on Saturday, 15 Shawwal 3 AH. If Hazrat Fatima's leave took place in Shawwal $3 \mathrm{AH}$ after the battle of Uhud, then her marriage should have taken place in Muharram $3 \mathrm{AH}$ (according to Sahib Isti'ab) or Rabi-ul-Awal 3 AH (according to Sahib Asad AlGhaba). Therefore, the statement of Muharram 2 $\mathrm{AH}$ in Asaba is not correct. From this point of view too, Hazrat Ayesha's departure from Hazrat Fatima can take place only four or four and a half months before Shawwal 2 AH. 2 AH means 15 prophecies. If Hazrat Ayesha was married in 10 Prophets and took leave in 15 Prophets as is well known and generally accepted, then the famous narration of Hazrat Ayesha that at the time of marriage Hazrat Ayesha was six years old and took leave She was nine years old at the time. It is wrong if at the time of marriage their age is increased to six years in 10 prophecies, then at the time of leave they should be eleven years in 15 prophecies $(2 \mathrm{AH})$ and not nine years.

Hazrat Ayesha's first engagement:

1 Sahih Bukhari, p, $8 / 3$

2 Ibnul Athir, Abul Hassan Ali bin Abi Al-Karam, Asadul Ghabah fi Maarifatul Shabah, Darul Fikr, Beirut, P, 540/ 5

3 Abu Amar, Yosuf bin Abdullah bin Muhammad bin Abdul Barr, Al-Estiaab Fi Maarifatul AlAshab, Darul Kutub Al-ilmiyah , Darul Fikr, Beirut, p, 540/5
All the companions of Sir agree that before the message from the Prophet (peace be upon him) Ayesha's relationship was discussed with the son of Jabir Ibn Mutam. And when the message of Hazrat Muhammad (PBUH) reached, Hazrat Abu Bakr Siddiq (PBUH) was most concerned about the fact that he had promised Jubair Ibn Mutam for Hazrat Ayesha How can they break this promise? This incident has been narrated by Maulana Syed Sulaiman Nadvi in Sira-ulNabawi as follows:

10 In the Prophethood, Hazrat Ayesha was married to him. She was six years old at the time. Before him, Jubayr was related to Ibn Mutam's son. After the death of Hazrat Khadija, Khula bint Hakeem proposed marriage to Hazrat Khadija. He agreed. Khula said to Umm Radman, she mentioned it to Hazrat Abu Bakr Siddiq, she said that I have made a promise to Jubair Ibn Mutam and I have never broken my promise. But Jubair himself refused on the grounds that if Hazrat Ayesha came to his house, Isla would step into the house. In any case, Hazrat Abu Bakr got married to him through Khula. Four hundred dirhams was declared a seal.4

There are two things to consider here. The first is that Ayesha's marriage to the Prophet (peace be upon him) at the age of six is mentioned, and before that she is related to Jubayr Ibn Mutam's son. Hazrat Ayesha was engaged to Ibn Mutam's son at the age of three or four years and was there any custom among the Arabs to get engaged to such small children? History does not show any such tradition. Secondly, it is clear from this statement that the move to break the engagement was not made by Hazrat Abu Bakr Siddiq but by Jubair himself, the reason given is that if Hazrat Ayesha If you come home, the step of Islam will come in the house. And only after the refusal did it become possible for Hazrat Siddiq Akbar to break the contract of Hazrat Ayesha with him. Here the question arises that if Ayesha was only six years old at the time of her marriage to him, then Jubair would have inevitably denied it before then. A sixyear-old girl who does not even have the manners to speak and understand can be considered worthy of Jubair's fear that if Hazrat Ayesha came to his house, he would follow Islam in the house. Will come What can be the reality of Islam and disbelief of a six year old girl. This in itself proves that Hazrat Ayesha was not six years old at that time as stated but was such an age that her Islam could be a threat to her in-laws and because of this danger Jubair refused. I thought it necessary to do.

4 Allama Shibli Numani, Seerat ul Nabi, Darul Musanifeen Shibli Academy India p, 406/2 
Hazrat Ayesha's scholarly superiority:

Some of the statements we find in the books of Hadith and Seer about the scholarly life of Hazrat Ayesha Siddiqah are given in the Sira of the Prophet (peace and blessings of Allaah be upon him) as a testimony to her greatness and knowledge.

The scholarly life of Hazrat Ayesha is also significant. Hazrat Abu Bakr used to give fatwas in the time of Hazrat Umar and Hazrat Uthman. 2210 hadiths have been narrated in which Shakhin has agreed on 174 hadiths. Bukhari has narrated 54 hadiths from them individually. Imam Muslim is unique in 68 hadiths. That whenever a difficult question was posed to the Companions, it was Hazrat Ayesha who would solve it. Her disciples say that we have not seen a happier speech than her. Tafsir, Hadith, Israr Shariat, Khatbat and Adab and Ansab I had perfected them. The great poems of the poets were memorized orally by Hakim in Mustadrak and Ibn Sa'd in Tabaqat. 1

Hazrat Urwah Ibn Al-Zubayr states:

I have never seen a woman better than Ayesha in medicine, jurisprudence and poetry. 2

Imam Zehri says:

If the knowledge of all the women of this ummah is collected, including the wives of the Prophet (peace and blessings of Allaah be upon him), then the knowledge of Aa'ishah will be greater than all of them.3

so far as Shariah sciences like Tafsir, Hadith, Fiqh, Israr Shariah etc. are concerned. Undoubtedly, all this knowledge was acquired by you through the grace and companionship of the Holy Prophet (sws) and this is by no means surprising or surprising. But along with these sciences and arts, oral recitation, medicine, genealogy, Arabic language, literature and memorization of the poems and long poems of the poets of Jahiliyyah are among the things which the time to learn cannot inevitably be what you spent in the company of the Prophet. There was no discussion of poetry in the house of the Holy Prophet. The poets of ignorance did not recite poems and there was no place for such things. There was no talk of genealogy in your house that Islam did not give any importance to relative distinction and superiority but the tendency of Islam was against it. Similarly, there was no opportunity for education and training in medicine and oratory. Inevitably, you will have acquired all

1 Seerat ul Nabi, p, 407-408/2

2 Al-Maghrabi, Muhammad bin Suleman, Jamul Fwaid, Maktabah Ibne Kathir Dare ibne Hazam, p, 234/2

3 Jamul Fwaid, P, 232/3 these sciences and arts in your own Mecca, because that was the opportunity for it. It is well known about Hazrat Abu Bakr Siddiq that:

Ibn Ishaq states that Abu Bakr Siddiq was the most genealogist of Arabia. Ajli said that he was the most knowledgeable about the Quraysh genealogy. Ibn Ishaq writes in Al-Sirat al-Kubra that Abu Bakr was a very beloved, and gentle man among his people. And the Quraysh were the most genealogical. And they were most aware of the merits and demerits of the genealogy. He was a very creative businessman. People loved him because of his knowledge, experience and good company. 4

Therefore, not all these sciences and arts could have been and would have been obtained from his father, but according to the abovementioned tradition, when he was only nine years old, he left Mecca and went to the Holy Shrine of the Holy Prophet (PBUH). Had been The human intellect cannot in any way believe that a nine-yearold girl can possess such skills in all these sciences and arts in her Mecca that her knowledge surpasses that of the women of the entire Ummah. And attain the status of perfection. If a boy or a girl is not able to learn anything before the age of seven, can a period of two years be considered sufficient for the completion of these sciences and arts? There is no woman more learned in jurisprudence than him. Inevitably, it has to be admitted that the tradition that Ayesha was nine years old at the time of her leave is either incorrect or has been disproved. Our view is that the word decade has been omitted from this narration by any narrator. Or intentionally omitted. As has been proved in Nos. (1), (2), (3). At the time of marriage, the age of Hazrat Ayesha is not less than sixteen or seventeen years and at the time of leave, it is not less than nineteen or twenty years. After so many evidences and proofs, this hadith cannot be accepted as authentic in any way.

In any case, this was a hadith whose authenticity cannot be objected to, but from the point of view of Da'wah, it is absolutely wrong.

Another tradition:

Some jurists have argued from another narration on the legitimacy of minor Age marriages, although this is probably not the Sahih narration. Because I could not find this narration in search of Sahih, but there is a narration anyway: The narration is:

Muhammad ibn Ishaq narrates that I was told by Abdullah ibn Abi Bakr ibn Hazm and

4 Al-Asqlani, Shahab ul Deen Ahmad bin Ali bin Hajar, Al-Isabah fi Maarifa Al-Shabah, Darul Kutub Al-Ilmiyah, Beirut, p, 334/2 
Abdullah ibn al-Harith and a man whom I do not consider guilty that Abdullah ibn Shaddad narrated that the man who married her to Umm Salma He was their son Salma, so the Prophet (peace and blessings of Allaah be upon him) had arranged his marriage to the daughter of Hazrat Hamza and they were both young children in those days, but they could not be reunited due to their death. Have I taken revenge on Salma for marrying me to her mother? 1

This tradition is not hidden from the scholars as it is in terms of authenticity. But even if this tradition is accepted as credible, it is not correct to argue that since the Prophet (peace and blessings of Allaah be upon him) had married these two young children. So even today it is permissible for everyone to do so. Regarding the Holy Prophet, the Holy Qur'an states:

The Prophet (pbuh) has more rights over Muslims than their souls.2

And no believing man or woman has the right to be free in any matter when Allah and His Messenger have decreed a matter. 3

Therefore, the Holy Prophet could have married Salma and bint Hamza even after puberty against their will. It doesn't matter if you are getting married as a minor or as an adult. But this feature was enjoyed only by the Holy Prophet. No one else in the ummah can claim it. Therefore, ordinary Muslims cannot be given the right to do so by speculating on his disposition.

One explanation for this tradition is that the word "spouse" is used figuratively in this tradition. In fact, you did not get married, but announced your engagement, but your announcement of engagement was also metaphorically interpreted as "marriage" because you had a certain kind of determination inside you.

Argument from Quranic verse:

The Holy Qur'an has declared puberty to be the age of marriage with a clear text, but it is ironic that in spite of this clear text, some of our scholars have tried to argue from the verses of the Holy Qur'an for minor Age marriages. He said. The ridiculousness of these arguments is a worthy lesson. At this time, I have before me the comment of the fourteen leading scholars of the country which has been published against the family laws and which has been given great publicity. These gentlemen write on this issue:

1 Al-Hanfi, Aljassas, Abu- Bakar Ahmad bin Ali, Ahkam ul Quran, Suhauil Academy Lahore, $1400 \mathrm{AH}, \mathrm{p}, 62 / 2$

2 Al-Ahzab, 33: 6

3 Al-Ahzab, 33: 36
The Holy Qur'an explicitly states that it is permissible to marry a girl who has not yet menstruated. Verse No. 4 of Surah Talaaq states that in the case of women whose menstruation has stopped or women who have not yet started menstruating, the 'iddah of divorce is three months. Now it is clear that the question of 'iddah divorce arises only when the previous marriage has taken place. Similarly, the Qur'an explicitly declares marriage to be permissible for a girl who has not started menstruating.

\section{The correct meaning of the verse}

In this verse, in fact, the ruling on 'iddah for women who have reached the age of puberty has been stated. They have had intercourse with their husbands but they are not recovering due to any illness or excuse. Examples of this type are common in women. Which can be confirmed today from every women's clinic. The evidence for this is also found in the same verse that the women who should have days are mentioned here but they are not getting days due to some excuse or illness. Every person who misses even the slightest bit of Arabic knows that in Arabic they come for simple and unusual and simple negation. And "lim" and "lama" come for the extraordinary, definite, that is, the negation of Hajj.

"Mahizan" or "Hazan" means "the days have not come to them" and "lam yahazan" and "lama yahazan" mean "they have never had days" or "they have not had any days yet". That is, the clause of emphasis can be used only when a claim is being made against it by the other party, at least as far as the requirements of the situation are concerned. Otherwise, using the clause of emphasis would be simply irrelevant and against the rules. If this is what our scholars want us to believe, then the word "mahzan" would be used here, because in the case of underage and minor girls, there is no claim by anyone that the days have come and the situation is not necessary. It is imperative that the days come. However, if the divorced woman is an adult. Her husband has also had an affair with her. In fact, she has already given birth to one and a half children, so the minimum requirement here is that the days have come or are coming for such a woman, but this is not happening due to some excuse or illness. Therefore, the use of emphasis on such an occasion is both appropriate and in accordance with the rules.

\section{SUMMARY}

However, if we look at the situation, more than 30 million girls in Pakistan are getting old due to lack of proper relationships and more than 300,000 young women have reached the age of marriage. Anyway, women are $52 \%$ and men are $48 \%$. In this modern age, waiting for the right relationship, girls themselves or their leaders are forced to find their relationship through the internet 
and social media. Therefore, in this way, most of them find their spouses, but due to not having a complete acquaintance with them, they also face many problems later. Most of the criminals lure the girls mentally by trapping them in the traps of heaven and earth and then use them in legitimate and illegitimate activities which have very dire consequences. Taking advantage of this compulsion, the relationship makers have also adopted different methods, the majority of which are in the cycle of earning a living only.

The growing number of unmarried girls and the lack of proper relationships has become a major problem in our society. Getting married is a natural thing that makes two families, but we have added to the difficulties for ourselves. Even after ten, fifteen, twenty years of puberty, we still give priority to the unjust customs and traditions of our status and society over marriage, preferring to get married after building a job, good business, house, car and other property. Yes, but by then the youth has begun to fade and finding such relationships that have been imprinted on the minds and hearts by the ideals, media, films and dramas is tantamount to gambling. Usually, our elders delay the marriages of young boys and prefer the marriages of daughters and sisters who are younger than their brothers. It is an inappropriate program not to bring one's daughter home as a daughter-inlaw at the moment, but to take the initiative to make one's daughter's hands pale as soon as possible, which also leads to a decrease in relationships. When the opportunity arises to cultivate a marital relationship with Allah, the snake with unwarranted demands from both sides comes out of the pot and prepares to bite, which affects the poor and middle class families for the rest of their lives. Engages in debt repayment. Promoting ignorant notions like community and caste also leads to a lack of relationships that we can't even think of having relationships with anyone other than our family, community or profession.

Marriage of young people at the right age cuts off the root of most of the misdeeds we have mentioned above in terms of results. It creates a chaotic society where psychologically strong personalities thrive. Marriage at the right age is the answer to the call of nature. Therefore, in particular, it eliminates the artificial demand for beauty that has cut young girls from all directions and brought them in front of the mirror. Hormones are fully activated in a young man between the ages of 15 and 22, so that any girl who comes into his life as a wife will be acceptable to him, regardless of his normal appearance. Why not girl Conversely, if there is no marriage at this age, the feelings created by the hormones that work inside the body will create in his mind a romantic outline of the opposite sex, which will be much more attractive than reality (including color). Our media is doing a lot of service to provide content for the sake of humiliation (for the sake of Allah). Who would be right to expect such a young man to be willing to marry a girl of modest stature at the age of thirty?

There are many objections to early marriage of young people. But all these objections are null and void. In this case, God expresses His will in the language of nature. When he first shows signs of puberty in a young man and a few years later mentally develops a strong desire for the opposite sex. Along with nature, he expresses the same will in his book. Take a look at the verse of Surah Noor which we have quoted above. It not only raises the issue of marriage but also responds to the only reasonable objection that arises against it. That is, the economic problem that arises after marriage. In his commentary on this verse, Maulana Amin Ahsan Islahi, the great commentator of the Qur'an, writes:

"As long as a man is deprived of his wife, he remains a bit of a gypsy. And many of his abilities are constricted and suppressed. In the same way, as long as a woman is deprived of her husband, her status is like that of an ox which is deprived of spreading and flourishing due to lack of support. But when a woman gets a husband and a man gets the companionship of a wife, both their abilities emerge and in the field of life when they both struggle together, Allah Almighty blesses their struggle and Their situation changes completely.

Those who object to this even after God's proclamation are wrong. In our opinion, no other opinion can ever be correct in a matter in which God makes His decision. If ever a problem arises as a result of this, the responsibility lies only on the wrong human attitudes, for example, marriage is a burden and the responsibilities that come after it are not made difficult by a god. This punishment is our own choice.

Keep in mind that it is not our intention to set a specific age for marriage. In social matters, it is not possible to say such a definitive thing. Every individual and family situation is different. So people take such a step just by looking at their situation. Our only emphasis is that young people should get married when they are really young. 